\title{
Acipimox stimulates leptin production from isolated rat adipocytes
}

\author{
Y-L Wang-Fisher, J Han and W Guo
}

Obesity Research Center, Boston University School of Medicine, 650 Albany Street, Boston, Massachusetts 02118, USA

(Requests for offprints should be addressed to W Guo; Email: wguo@bu.edu)

\begin{abstract}
Acipimox is a nicotinic acid-derived antilipolytic drug devoid of major side effects, and has been used in a number of human trials. This work reports the effects of Acipimox on leptin production from isolated rat adipocytes, in comparison with nicotinic acid and insulin. For cells isolated from normal animals, all these three reagents stimulated leptin release to a similar extent. Acipimox and nicotinic acid were more potent than insulin in stimulating leptin release from cells isolated from diabetic animals,
\end{abstract}

probably because of impaired insulin sensitivity in cells from these diseased animals. Co-incubation of Acipimox with norepinephrine or dibutyryl cAMP diminished its stimulatory effects on leptin release, in parallel with increased lipolysis, suggesting that intracellular free fatty acids play an important role in mediating leptin production in adipocytes.

Journal of Endocrinology (2002) 174, 267-272

\section{Introduction}

Being a satiety hormone predominantly produced from adipose tissue, leptin has been proposed to play important roles in regulating body energy balance. The impairment of this energy balance leads to obesity, which is becoming a prevailing disease that affects the whole world. Obesity is associated with elevated plasma free fatty acid (FFA) concentrations caused by impaired insulin suppression of adipocyte lipolysis. Some prior studies suggest that FFA or their acyl CoA products inhibit leptin production (Rentsch \& Chiesi 1996, Deng et al. 1997, Shintani et al. 2000), whereas others show that decrease in plasma FFA caused by infusion of Acipimox does not change plasma leptin concentrations in the short term (Hennes et al. 1997, Peino et al. 1998, Stumvoll et al. 2000). In a recent study, a 3-day treatment with Acipimox was found to lower plasma FFA, triglycerides (TG), glucose, and insulin, and also significantly increase plasma leptin level (Worm 2000 et al.). Because insulin stimulation on leptin production has been well documented both in vivo and in vitro, increased leptin levels induced by Acipimox treatment is not likely to be a secondary effect of decreased insulin production. It suggests that Acipimox may have a direct effect on leptin production. The discrepancy between the long-term and short-term studies indicates the effect of Acipimox on leptin production may be a chronic effect. Alternatively, since leptin production is regulated by various factors in vivo, the effects of Acipimox may not become clear until other factors are coordinately regulated. In this regard, an in vitro system may be valuable; for it allows an investigation of extrinsic factor(s) in the absence of homeostatic compensatory mechanisms commonly found in vivo.

Isolated primary adipocytes have been widely used as an in vitro model system to study individual factors that influence cell functions, including leptin production (Mueller et al. 1998, Shintani et al. 2000, Wang et al. 2002). In this work, we investigated how Acipimox modulates leptin secretion and other metabolic events in freshly isolated rat adipocytes from normal, streptozotocin (STZ)-diabetic, Zucker diabetic fat (ZDF) and Zucker lean (Z-lean) rats. Our results demonstrated a close similarity between Acipimox and insulin on their effects on leptin production from cells isolated from normal animals. However, Acipimox is more potent than insulin in stimulating leptin production from cells isolated from diabetic rats.

\section{Material and Methods}

\section{Chemicals}

Acipimox (5-methyl-pyrazine-2-carboxylic acid-4-oxide) was obtained from Pharmacia (Spa, Italy). Collagenase (type II), BSA (fraction V), STZ, insulin powder (porcine), nicotinic acid, dibutyryl cAMP ( $\left.\mathrm{Bt}_{2}-\mathrm{cAMP}\right)$, norepinephrine (NE) bitartrate and other chemicals were purchased from Sigma Co. (St Louis, MO, USA). Rat leptin RIA kit was purchased from Linco Research Inc. (St Charles, MO, USA).

\section{Animals}

Normal female Sprague-Dawley rats (280-300 g) were purchased from Charles River Laboratory (Wilmington, 
Table 1 The plasma parameters $(n=6$, means \pm S.E.M. $)$ in non-fasting rats at the time of experiments

\begin{tabular}{|c|c|c|c|c|}
\hline & Wild-type & STZ-diabetic & Z-lean & ZDF \\
\hline Insulin (ng/ml) & $19 \cdot 5 \pm 5$ & $0 \cdot 7 \pm 0 \cdot 1$ & $14 \cdot 5 \pm 0 \cdot 9$ & $29 \cdot 1 \pm 0 \cdot 9$ \\
\hline Glucose $(\mathrm{mg} / \mathrm{ml})$ & $109 \pm 4 \cdot 1$ & $744 \pm 83$ & $113 \pm 6 \cdot 2$ & $289 \pm 24$ \\
\hline Leptin $(\mathrm{ng} / \mathrm{ml})$ & $1 \cdot 3 \pm 0 \cdot 3$ & $0 \cdot 5 \pm 0 \cdot 02$ & $6 \cdot 7 \pm 0 \cdot 9$ & $24 \cdot 6 \pm 1 \cdot 7$ \\
\hline Triglycerides (mg/dl) & $62 \pm 3$ & $194 \pm 9$ & $200 \pm 16$ & $511 \pm 25$ \\
\hline
\end{tabular}

MA, USA). STZ-diabetic rats were prepared by peritoneal injection of STZ $50-60 \mathrm{mg} / \mathrm{kg}$. After 3-5 days of injection, blood glucose and urinary glucose levels were tested to confirm diabetic status and rats were ready for use. ZDF rats $(290-330 \mathrm{~g}, \mathrm{fa} / \mathrm{fa})$ and Z-lean rats $(280-300 \mathrm{~g})$ were purchased from Genetic Models Inc. Indianapolis, IN, USA. All animals were housed with free access to laboratory chow and tap water, with a photoperiod of $12 \mathrm{~h}$ light: $12 \mathrm{~h}$ darkness at $26^{\circ} \mathrm{C}$. The plasma leptin, insulin, glucose and TG levels of these animals at the time of experiments are listed in Table 1.

\section{Adipocyte preparation}

White adipocytes were prepared from perirenal fat pads of non-fasting animals by collagenase digestion with Rodbell's method with slight modification as described before (Rodbell 1967, Wang et al. 2002). The isolated adipocytes were finally washed with $5 \mathrm{ml}$ Krebs-Ringer bicarbonate (KRB) containing 4\% BSA and diluted at a concentration of $0 \cdot 15-0.25 \times 10^{6}$ cells $/ \mathrm{ml}$ in $\mathrm{KRB}$ (glucose $2.7 \mathrm{mM}$, BSA $4 \%$, pH 7.4). The cell numbers were counted in a hemacytometer after trypan blue staining.

\section{Leptin and glycerol release}

Isolated adipocytes were incubated with insulin, Acipimox or nicotinic acid alone for up to $4 \mathrm{~h}$ at $37^{\circ} \mathrm{C}$ with shaking in a water bath at 40 cycles/min. NE or $\mathrm{Bt}_{2}$-cAMP was added to selected incubations together with Acipimox. The release of leptin or glycerol was determined as described before (Wang et al. 2002).

\section{Statistical analysis}

StatView II, DeltaGraph software was used to process the data (F-test). Results are shown as means \pm s.E.M.

\section{Results}

\section{Acipimox-stimulated leptin secretion in adipocytes from} normal rats

While the acute effects of Acipimox on leptin production were not detected in vivo (Stumvoll et al. 2000), its stimulation was rapidly detected in vitro. As shown in Fig. 1A, within $2 \mathrm{~h}$ of incubation, there was about $50 \%$ increase in leptin release from cells incubated with Acipimox as compared with the control, in agreement with the rapid time course of drug-induced changes in leptin expression reported before (Chen et al. 1999). Nicotinic acid caused a similar level of stimulation on leptin release under identical conditions. Both demonstrated an insulin mimicking effect (Fig. 1A). At the end of $4 \mathrm{~h}$ of incubation, leptin release from the treated cells was more than 2-fold of the control (Fig. 1A). Figure 1B shows the dose-dependent stimulation of Acipimox on leptin release. Below $10^{-6} \mathrm{M}$, Acipimox showed essentially no effect on leptin release. From $10^{-5} \mathrm{M}$ to $10^{-3} \mathrm{M}$, there was a rapid increase in leptin release as a function of Acipimox concentration and this effect was saturated beyond $10^{-3} \mathrm{M}$. The dose-response pattern was the same for Acipimox/nicotinic acid $\left(10-10 \mathrm{mM}, \mathrm{EC}_{50}\right.$ $\sim 0.5 \mathrm{mM})$ and resembled that of insulin (0.001-100 nM, $\left.\mathrm{EC}_{50} \sim 1 \mathrm{nM}\right)$. Maximal stimulation was higher for Acipimox/nicotinic acid than insulin $\left(3.85\right.$ vs $3.25 \mathrm{ng} / 10^{6}$ cells, $P<0 \cdot 05)$.

Acipimox-stimulated leptin release in adipocytes from diabetic rats

Adipose tissue leptin mRNA and plasma leptin level have been found to decrease in insulin-deficient (type 1) diabetic donors (Sivitz et al. 1996). Treatment by insulin restored the leptin production in vivo (Sivitz et al. 1996, Ahmed et al. 2001). To test whether this can be a direct effect of insulin on adipocytes and whether such actions can be mimicked by Acipimox, effects of these agents on leptin production from adipocytes of STZ-diabetic rats were determined. As shown in Fig. 2, incubation with insulin or Acipimox significantly increased leptin release. However, insulin stimulation was clearly less potent on cells from the STZ animals than those from the control, whereas Acipimox had a similar stimulation on both (Fig. 2). These results are consistent with the previous study that shows adipocytes of STZ-diabetic rats had reduced sensitivity to insulin (Nishimura et al. 1989). We next looked into the animal model of type 2 diabetes, the ZDF rats. Similar to the results shown above, basal leptin release was similar from adipocytes from Z-lean and ZDF 


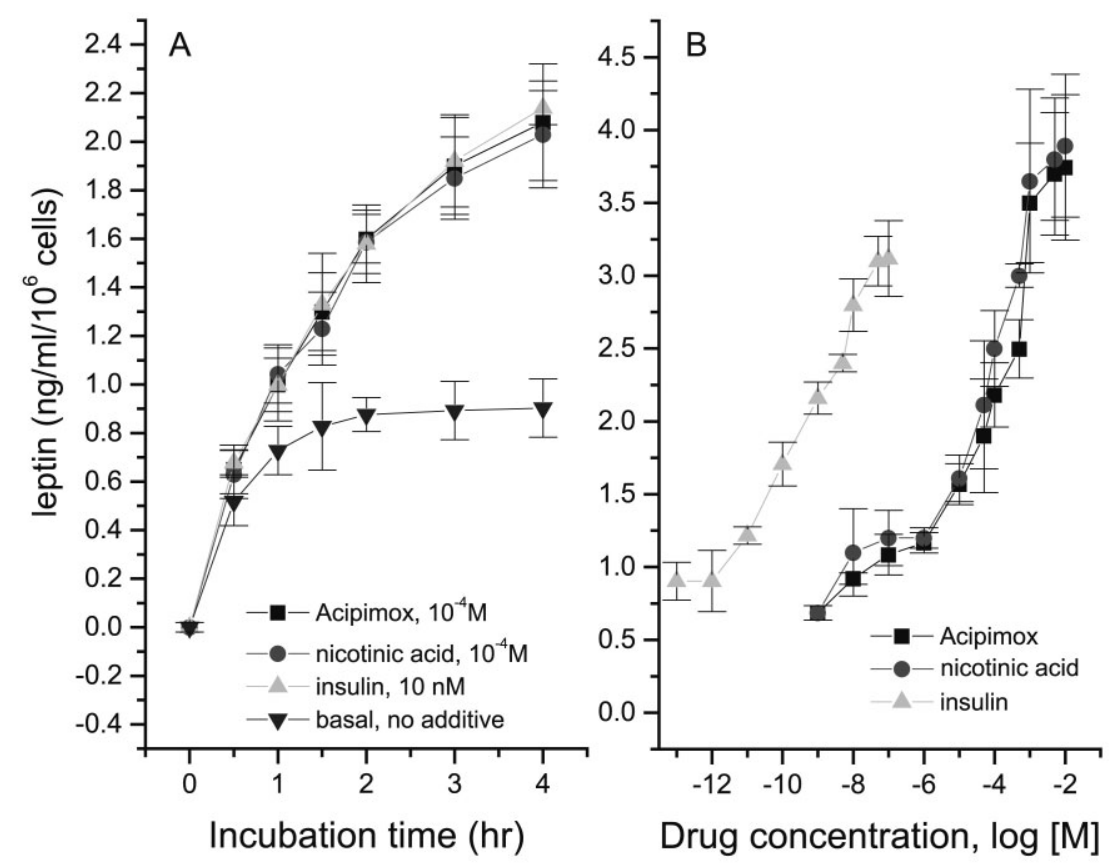

Figure 1 Insulin, Acipimox, and nicotinic acid enhanced leptin release from adipocytes isolated from Sprague-Dawley rats in a time- (A) and dose- (B) dependent manner $(n=6$ for each data point, means \pm S.E.M.). The symbols for different reagents are labeled within each graph.

rats (Fig. 2). Both insulin and Acipimox stimulated leptin release (Fig. 2). However, insulin stimulation was less potent for ZDF adipocytes than for the Z-lean, whereas

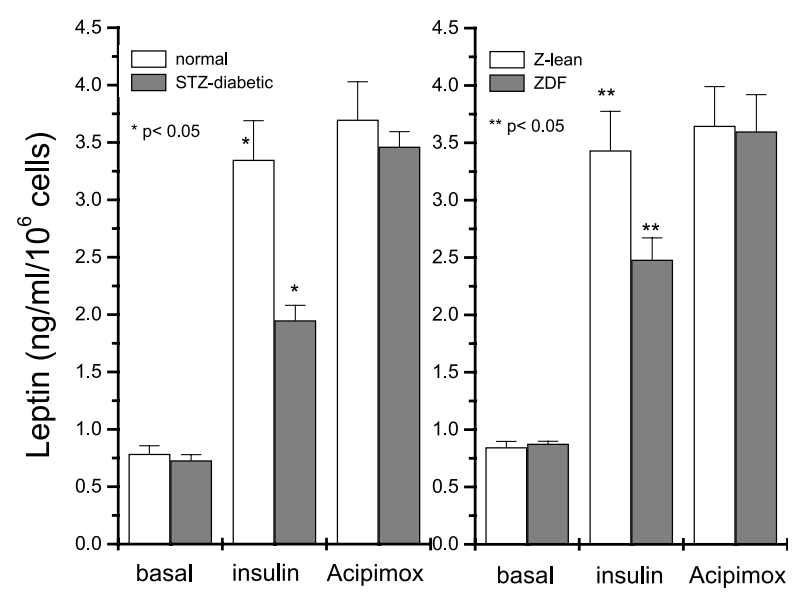

Figure 2 Acipimox $\left(10^{-2} \mathrm{M}\right)$ stimulated leptin release more potently than insulin $\left(10^{-7} \mathrm{M}\right)$ in adipocytes from streptozotocin (STZ)-treated and Zucker diabetic fat (ZDF) rats. Incubation conditions are labeled within each graph $(n=6$, means \pm S.E.M.). The data shown here were obtained using insulin or Acipimox at the concentrations of $100 \times \mathrm{EC}_{50}$ value. Similar results were obtained using the stimulants at lower concentrations (not shown).
Acipimox stimulation was almost the same for adipocytes of both types of rats.

Note that adipocytes from both types of diabetic rats have similar basal leptin release as control (Fig. 2), in contrast to the large difference found in the corresponding plasma leptin concentrations (Table 1). This discrepancy is probably caused by the difference in the hormonal and nutritional conditions in vivo and in vitro as described before (Wang et al. 2002).

\section{NE inhibits Acipimox-stimulated leptin release}

NE has been shown to diminish insulin-stimulated leptin release in rat adipocytes (Gettys et al. 1996). To determine whether it also affects the stimulatory effects of Acipimox, adipocytes from Sprague-Dawley rats were incubated with NE and Acipimox at various concentrations. As shown in Fig. 3, at fixed NE concentration $\left(10^{-5} \mathrm{M}\right)$, increase of Acipimox stimulated leptin release dosedependently. However, at any given concentration of Acipimox, the presence of NE largely reduced the leptin release compared with that in the absence of NE (Fig. 3 vs Fig. 1B). At a sub-optimal concentration of Acipimox $\left(10^{-3} \mathrm{M}\right)$, its stimulation on leptin release was attenuated with increasing $\mathrm{NE}$ concentrations (Fig. 3, $\mathrm{IC}_{50}$ $\sim 0.25 \mu \mathrm{M})$. This is similar to a prior report that NE inhibits insulin-stimulated leptin release $\left(\mathrm{IC}_{50} \sim 0 \cdot 1 \mu \mathrm{M}\right.$ 


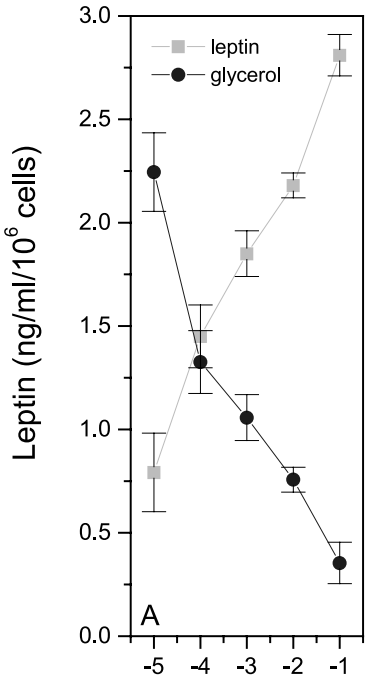

[Acipimox], M

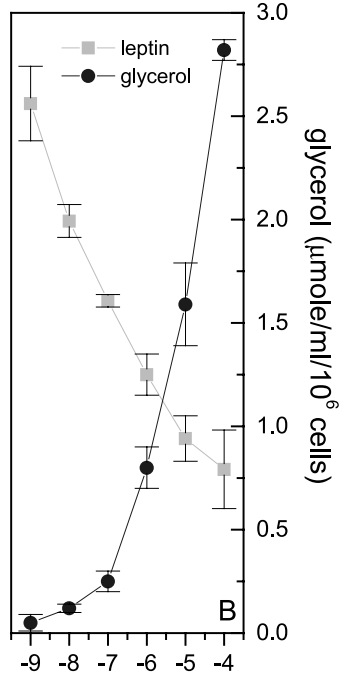

[NE], M
Figure 3 Norepinephrine (NE) inhibited Acipimox-mediated leptin release at fixed $\mathrm{NE}$ concentration of $10^{-5} \mathrm{M}$ and variable Acipimox concentration or at fixed Acipimox concentration of $10^{-3} \mathrm{M}$ and variable NE concentration. In both panels, leptin concentration is shown on the left side, and glycerol release is shown on the right side $(n=6$, means \pm S.E.M. $)$.

(Gettys et al. 1996)). The NE-mediated decrease in leptin release was accompanied with a simultaneous increase in glycerol release (Fig. 3). Co-incubation of adipocytes with $\mathrm{Bt}_{2}$-cAMP and Acipimox also diminishes the stimulatory effects of Acipimox on leptin release in a similar pattern as NE (Fig. 4), consistent with prior reports that increased intracellular cAMP is associated with decreased leptin production (Gettys et al. 1996, Kosaki et al. 1996, Slieker et al. 1996).

\section{Discussion}

This study is, to our knowledge, the first report that Acipimox, similar to insulin, acutely stimulated the leptin release in isolated primary rat adipocytes. Moreover, we showed that while insulin-stimulated leptin production was impaired for cells from diabetic animals, the stimulatory effect of Acipimox was essentially not affected (Fig. 2). Like some other insulin mimicking reagents, Acipimox may bypass the membrane receptor control to reach the target regulatory machinery via alternative pathways.

Previous studies suggest that acute regulation of leptin production by $\beta$-adrenoceptor agonists is mediated via the second messenger cAMP (Kosaki et al. 1996, Deng et al. 1997, Donahoo et al. 1997, Coya et al. 2001), although an alternative cAMP-independent signal pathway may be involved (Stumvoll et al. 2000). Nevertheless, our data showed that Acipimox stimulation was efficiently suppressed by both $\mathrm{NE}$ and $\mathrm{Bt}_{2}-\mathrm{cAMP}$, consistent with the

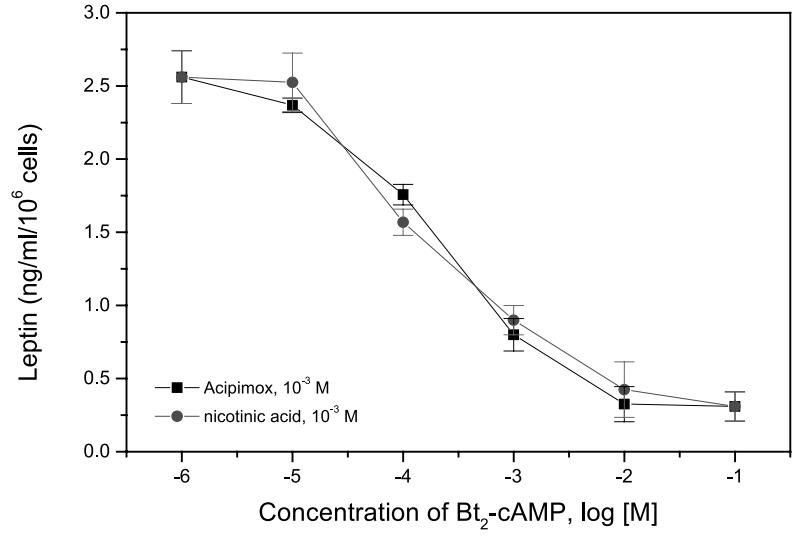

Figure 4 Dibutyryl $\left(\mathrm{Bt}_{2}\right)$-cAMP antagonized the stimulatory effects of Acipimox or nicotinic acid on leptin release $(n=6$, means \pm S.E.M.).

hypothesis that Acipimox acts mainly via its inhibition on cAMP production. Since the ultimate result of increased cAMP is the rise in FFA release, the intracellular FFA level may play key roles in this process (Sivitz 1996, Havel et al. 1998, Shintani et al. 2000). Indeed, in cultured 3T3-L1 adipocytes, incubation with FFA exerts a concentrationdependent inhibition of leptin transcription whereas an elevation of cAMP alone displayed only a marginal effect (Rentsch \& Chiesi 1996).

The molecular mechanisms that control leptin production are still not well understood. It has been shown that the adipogenic transcription factor $\mathrm{C} / \mathrm{EBP} \alpha$ binds to the leptin promoter and activates its transcription ( $\mathrm{He}$ et al. 1995, de la Brousse et al. 1996, Hwang et al. 1996). Although direct interaction between FFA and C/EBP $\alpha$ has not been established, indirect interactions may be mediated by peroxisome proliferator-activated receptor- $\gamma$ (PPAR $-\gamma$, the ligand-activated adipocyte specific nuclear transcription factor (Hamm et al. 2001)). Activation of PPAR $-\gamma$ by its pharmacological ligand suppresses the transcription of leptin gene (De Vos et al. 1996, Kallen \& Lazar 1996, Nolan et al. 1996). FFAs have been shown to bind and activate PPAR- $\gamma$ in vitro (Kliewer et al. 1997), and may act as endogenous ligands for this transcription factor (Grimaldi et al. 1999). The suppression of leptin gene expression by elevated FFA might be mediated via the activation of PPAR- $\gamma$ (Shintani et al. 2000). In this regard, Acipimox-stimulated leptin production could be caused by FFA-mediated changes in PPAR- $\gamma$ activity.

A few recent studies show that leptin induces lipolysis in adipocytes (Wang et al. 1999, Kawaji et al. 2001, Yamagishi et al. 2001). Meanwhile, exogenous leptin also increases the expression and enzyme activities of carnitine palmitoyl transferase-1 (CPT-1) and decreases that of acetyl CoA carboxylase (ACC), the two key enzymes that control FFA oxidation (Wang et al. 1999, Yamagishi et al. 


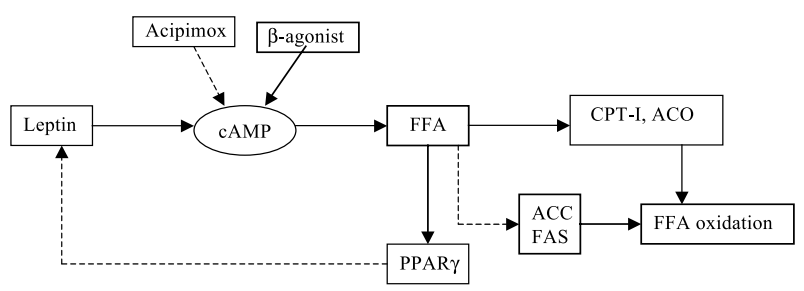

Figure 5 A schematic model of the leptin-FFA regulatory loop. Solid lines indicate stimulation, whereas dashed lines indicate inhibition. ACC, acetyl COA carboxylase; ACO, acyl CoA oxidase; CPT-I, carnitine palmitoyl transferase-1; FAS, fatty acid synthase.

2001). It should be noted that CPT-1 and acyl CoA oxidase (ACO) as well as their transcription factor, PPAR- $\alpha$, are regulated by FFA (Sleboda et al. 1999, Geelen et al. 2001). Therefore, leptin-induced activation of $\beta$-oxidation might be actually mediated by leptinstimulated lipolytic FFA release. When increased $\beta$-oxidation can no longer accommodate the rise of intracellular FFA release, endogenous leptin production is inhibited. Such a leptin-FFA regulatory loop is schematically summarized in Fig. 5.

Under our experimental conditions, inhibition on leptin production by FFA could have become significant after the adipose tissue was dissected and processed in the KRB buffer, with a moderately low glucose concentration $(2.7 \mathrm{mM})$, high BSA concentration and no insulin, the conditions resembling starvation. In this case, basal FFA release was relatively high (data not shown). Adding Acipimox to this system inhibited FFA release and removed its inhibition on leptin production, leading to increased leptin release (Fig. 1). Our model does not seem to agree with a prior report that shows no effect on plasma leptin concentration caused by acute changes in plasma FFA in vivo (Peino et al. 1998). However, in this study, plasma FFA was elevated by i.v. infusion of intralipid with heparin. In this case, the intracellular FFA in adipocytes might not be significantly affected. Alternatively, changes of various compensatory factors in vivo may mask its effects on leptin production (Leal-Cerro et al. 1997).

In summary, although circulating leptin level is usually increased in obesity, leptin production per equivalent unit of fat mass is reduced (Surwit et al. 1997, Watson et al. 2000). Moreover, hyperinsulinemia commonly found in obese subjects causes elevated basal leptin levels but diminishes hormone-stimulated leptin expression, and diminishes the metabolic regulatory functions of leptin. Our findings that Acipimox-stimulated leptin production is not impaired by diabetes-induced receptor malfunctioning warrant further investigation on this drug for the regulation of fat mass development.

\section{Acknowledgement}

This work was supported by NIH DK59261.

\section{References}

Ahmed ML, Ong KK, Watts AP, Morrell DJ, Preece MA \& Dunger DB 2001 Elevated leptin levels are associated with excess gains in fat mass in girls, but not boys, with type 1 diabetes: longitudinal study during adolescence. Journal of Clinical Endocrinology and Metabolism 86 1188-1193.

de la Brousse FC, Shan B \& Chen JL 1996 Identification of the promoter of the mouse obese gene. PNAS 93 4096-4101.

Chen XL, Dean RG \& Hausman GJ 1999 Expression of leptin mRNA and CCAAT-enhancer binding proteins in response to insulin deprivation during preadipocyte differentiation in primary cultures of porcine stromal-vascular cells. Domestic Animal Endocrinology 17 389-401.

Coya R, Gualillo O, Pineda J, Garcia MC, Busturia MA, Aniel-Quiroga A, Martul P \& Senaris RM 2001 Effect of cyclic $3^{\prime}, 5^{\prime}$-adenosine monophosphate, glucocorticoids, and insulin on leptin messenger RNA levels and leptin secretion in cultured human trophoblast. Biology of Reproduction 65 814-819.

Deng C, Moinat M, Curtis L, Nadakal A, Preitner F, Boss O, Assimacopoulos-Jeannet F, Seydoux J \& Giacobino JP 1997 Effects of beta-adrenoceptor subtype stimulation on obese gene messenger ribonucleic acid and on leptin secretion in mouse brown adipocytes differentiated in culture. Endocrinology 138 548-552.

De Vos P, Lefebvre AM, Miller SG, Guerre-Millo M, Wong K, Saladin R, Hamann LG, Staels B, Briggs MR \& Auwerx J 1996 Thiazolidinediones repress ob gene expression in rodents via activation of peroxisome proliferator-activated receptor gamma. Journal of Clinical Investigation 98 1004-1009.

Donahoo WT, Jensen DR, Yost TJ \& Eckel RH 1997 Isoproterenol and somatostatin decrease plasma leptin in humans: a novel mechanism regulating leptin secretion. Journal of Clinical Endocrinology and Metabolism 82 4138-4143.

Geelen SN, Blazquez C, Geelen MJ, Sloet van OldruitenborghOosterbaan MM \& Beynen AC 2001 High fat intake lowers hepatic fatty acid synthesis and raises fatty acid oxidation in aerobic muscle in Shetland ponies. British Journal of Nutrition 86 31-36.

Gettys TW, Harkness PJ \& Watson PM 1996 The beta 3-adrenergic receptor inhibits insulin-stimulated leptin secretion from isolated rat adipocytes. Endocrinology 137 4054-4057.

Grimaldi PA, Teboul L, Gaillard D, Armengod AV \& Amri EZ 1999 Long chain fatty acids as modulators of gene transcription in preadipose cells. Molecular and Cellular Biochemistry 192 6368.

Hamm JK, Park BH \& Farmer SR 2001 A role for C/EBPbeta in regulating peroxisome proliferator-activated receptor gamma activity during adipogenesis in 3T3-L1 preadipocytes. Journal of Biological Chemistry 276 18464-18471.

Havel PJ, Uriu-Hare JY, Liu T, Stanhope KL, Stern JS, Keen CL \& Ahren B 1998 Marked and rapid decreases of circulating leptin in streptozotocin diabetic rats: reversal by insulin. American Journal of Physiology 274 R1482-R1491.

He Y, Chen H, Quon MJ \& Reitman M 1995 The mouse obese gene. Genomic organization, promoter activity, and activation by CCAAT/enhancer-binding protein alpha. Journal of Biological Chemistry 270 28887-28891.

Hennes MM, Dua A, Maas DL, Sonnenberg GE, Krakower GR \& Kissebah AH 1997 Relationships of plasma leptin levels to changes in plasma free fatty acids in women who are lean and women who are abdominally obese. Obesity Research 5 442-446.

Hwang CS, Mandrup S, MacDougald OA, Geiman DE \& Lane MD 1996 Transcriptional activation of the mouse obese (ob) gene by CCAAT/enhancer binding protein alpha. PNAS 93 873-877.

Kallen CB \& Lazar MA 1996 Antidiabetic thiazolidinediones inhibit leptin (ob) gene expression in 3T3-L1 adipocytes. PNAS 93 5793-5796.

Kawaji N, Yoshida A, Motoyashiki T, Morita T \& Ueki H 2001 Anti-leptin receptor antibody mimics the stimulation of lipolysis 
induced by leptin in isolated mouse fat pads. Journal of Lipid Research 42 1671-1677.

Kliewer SA, Sundseth SS, Jones SA, Brown PJ, Wisely GB, Koble CS, Devchand P, Wahli W, Willson TM, Lenhard JM \& Lehmann JM 1997 Fatty acids and eicosanoids regulate gene expression through direct interactions with peroxisome proliferator-activated receptors alpha and gamma. PNAS 94 4318-4323.

Kosaki A, Yamada K \& Kuzuya H 1996 Reduced expression of the leptin gene (ob) by catecholamine through a $G(S)$ protein-coupled pathway in 3T3-L1 adipocytes. Diabetes 45 1744-1749.

Leal-Cerro A, Jimenez LM, Astorga R, Fernandez-Lopez I, Dieguez C \& Casanueva FF 1997 Acute pharmacological reduction of plasma free fatty acids enhances the growth hormone (GH)-releasing hormone-mediated GH secretion in patients with Cushing's syndrome. Journal of Clinical Endocrinology and Metabolism 82 3165-3168.

Mueller WM, Gregoire FM, Stanhope KL, Mobbs CV, Mizuno TM, Warden CH, Stern JS \& Havel PJ 1998 Evidence that glucose metabolism regulates leptin secretion from cultured rat adipocytes. Endocrinology 139 551-558.

Nishimura H, Kuzuya H, Okamoto M, Yamada K, Kosaki A, Kakehi T, Inoue G, Kono S \& Imura H 1989 Postreceptor defect in insulin action in streptozotocin-induced diabetic rats. American Journal of Physiology 256 E624-E630.

Nolan JJ, Olefsky JM, Nyce MR, Considine RV \& Caro JF 1996 Effect of troglitazone on leptin production. Studies in vitro and in human subjects. Diabetes 45 1276-1278.

Peino R, Fernandez Alvarez J, Penalva A, Considine RV, RodriguezSegade S, Rodriguez-Garcia J, Cordido F, Casanueva FF \& Dieguez C 1998 Acute changes in free-fatty acids (FFA) do not alter serum leptin levels. Journal of Endocrinological Investigation 21 526-530.

Rentsch J \& Chiesi M 1996 Regulation of ob gene mRNA levels in cultured adipocytes. FEBS Letters 379 55-59.

Rodbell M 1967 Metabolism of isolated fat cells. VI. The effects of insulin, lipolytic hormones, and theophylline on glucose transport and metabolism in 'ghosts'. Journal of Biological Chemistry 242 $5751-5756$.

Shintani M, Nishimura H, Yonemitsu S, Masuzaki H, Ogawa Y, Hosoda K, Inoue G, Yoshimasa Y \& Nakao K 2000 Downregulation of leptin by free fatty acids in rat adipocytes: effects of triacsin C, palmitate, and 2-bromopalmitate. Metabolism: Clinical and Experimental 49 326-330.
Sivitz WI, Walsh S, Morgan D, Donohoue P, Haynes W \& Leibel RL 1996 Plasma leptin in diabetic and insulin-treated diabetic and normal rats. Metabolism: Clinical and Experimental 47 84-91.

Sleboda J, Risan KA, Spydevold O \& Bremer J 1999 Short-term regulation of carnitine palmitoyltransferase I in cultured rat hepatocytes: spontaneous inactivation and reactivation by fatty acids. Biochimica et Biophysica Acta 1436 541-549.

Slieker LJ, Sloop KW, Surface PL, Kriauciunas A, LaQuier F, Manetta J, Bue-Valleskey J \& Stephens TW 1996 Regulation of expression of ob mRNA and protein by glucocorticoids and cAMP. Journal of Biological Chemistry 271 5301-5304.

Stumvoll M, Fritsche A, Tschritter O, Lehmann R, Wahl HG, Renn W \& Haring H 2000 Leptin levels in humans are acutely suppressed by isoproterenol despite acipimox-induced inhibition of lipolysis, but not by free fatty acids. Metabolism 49 335-339.

Surwit RS, Petro AE, Parekh P \& Collins S 1997 Low plasma leptin in response to dietary fat in diabetes- and obesity-prone mice. Diabetes 46 1516-1520.

Wang MY, Lee Y \& Unger RH 1999 Novel form of lipolysis induced by leptin. Journal of Biological Chemistry 274 17541-17544.

Wang Y, Han J, Zang Y \& Guo W 2002 The effects of vanadate on leptin production from isolated rat preadipocytes. Bioactive Trace Element Research 85 171-182.

Watson PM, Commins SP, Beiler RJ, Hatcher HC \& Gettys TW 2000 Differential regulation of leptin expression and function in $\mathrm{A} / \mathrm{J}$ vs C57BL/6J mice during diet-induced obesity. American Journal of Physiology. Endocrinology and Metabolism 279 E356-E365.

Worm D, Vinten J, Vaag A, Henriksen JE \& Beck-Nielsen H 2000 The nicotinic acid analogue acipimox increases plasma leptin and decreases free fatty acids in type 2 diabetic patients. European Journal of Endocrinology 143 389-395.

Yamagishi SI, Edelstein D, Du XL, Kaneda Y, Guzman M \& Brownlee M 2001 Leptin induces mitochondrial superoxide production and monocyte chemoattractant protein-1 expression in aortic endothelial cells by increasing fatty acid oxidation via protein kinase A. Journal of Biological Chemistry 276 25096-25100.

Received in final form 14 March 2002

Accepted 8 April 2002 